\title{
Transformation of Knights with Magic
}

\author{
Tanner Strong ${ }^{\mathrm{a}}$
}

This paper explores the idea of how fairies were able to shape the identities of knights within the medieval time period. It will discuss two main fairies, Morgan le Fay and the fairy from Marie de France's Lanval. A history of magic is reviewed to have a better understanding of what witches and an enchantresses were like in this time period followed by a disucssion of a fairy's true role in society at that time.

Curiously, given our understanding of the medieval world, twelfth century texts demonstrate a strong use of magic, magic that seemed to function in a way that helped characters to be better people or perform their tasks more effectively... Authors wrote about magic and made it appealing. Medieval audiences should have been against the idea of magic, but given the frequency of its use, that does not seem to be the case. These authors were able to re-write magic as a powerful form of benefit to characters - it helps in the shaping their own identities. We see this in the case of numerous knights, who were able to progress in life through the use of magic.

For example, two knights, Gawain and Lanval, are both ostracized from society and are in need of help. Lanval is ostracized by how he has no one to count on; he has no social class status, and was forgotten by nearly every single person in the kingdom. Gawain is seen as someone who is arrogant and too busy being oblivious to even notice that he is walking down the wrong path. Both are challenged by social contexts of society and in the end they both are transformed by magic to give them a new identity. Morgan le Fay transforms Gawain by allowing him to venture out on his own and passing tests of courage and wisdom. Lanval is transformed by a fairy that comes to him in his time of need that happens twice and allows him to be saved from those around him who were corrupt such as Guinevere and Arthur's court. Both knights would not have been transformed if it were not for the use of magic. Magic seems to be needed to help shape these characters into better human beings, men more consciously aware of their surroundings and able to see past temptations from their corrupted society.

This paper will provide a deeper analysis of how magic was needed/used in Arthurian romance to transform knights into the true definition of knighthood. Both Morgan le Fay and the fairy that shapes Lanval show promising aspects of magic doing just deeds in order to save a person from their ostracizing in society. Gawain who was threatened to be banished and brought to death was allowed to move freely after passing the trial of his Aunt, Morgan le Fay. If it were not for her, Gawain would have continued on the path of both pride and gluttony. Two of the seven deadly sins that were well known in this time period and are continued to be seen throughout medieval texts.

Magic has been a perpetual part throughout history leaving an ever-lasting impression for it to be still relevant in the world today. In the past those who were seen as witches in the twelfth century showed a resemblance of fear to those who were considered as normal. Magic was a social no-no and those who were involved were burned at the stake due to accusations and fear of being different. However we see this in a new light when we compare the fear of magic in writings that were used for stories. These stories were written and told to many audiences in order to scare them into behaving because if one were to sin they would end up in hell. One of the most remarkable ideas behind King Arthur and his friends is that magic is seen as a positive and not a negative. Prophets and fairies are seen on and off throughout the texts. Both Morgan le Fay from the Pearl Poet and Geoffrey of Monmouth show her as someone who uses magic to her advantage. When Marie de France wrote about a fairy who was even prettier than Guinevere the audience knows that she was not messing around with the role of magic in this time period. The Middle Ages therefore knew two types of fairies: the Parcae whose classical image had been profoundly transformed by popular tradition; and, the ladies of the forest whose path often crosses that of mortals. In the twelfth century the latter became fairies when they entered into learned culture and as the word fairy became progressively disjoined from the character of the Parcae. ${ }^{\mathrm{i}}$

Magic has always been seen as something that was a mixture of confusion with a splash of acceptance depending on where and who you were in medieval text, but magic in real life was deeply frowned upon. In Richard Kieckhefer's book, "Magic in the Middle Ages" he examines the role of magic within the Middle Aged period and how it can be interpreted in different key concepts. He focuses on the term magic as a source of power by claiming that "magic" will be a term used for those phenomena, which intellectuals would have recognized as either demonic or natural magic. That which makes an action magical is the type of power it invokes: if it relies on divines action or the manifest powers of nature it is not magical, while if it uses demonic aid or occult powers in nature it is magical. ${ }^{\text {ii }}$ Resulting in the idea of how magic can be interpreted differently amongst those who are historians. As researchers we have to keep an open mind in order to understand the concepts of how Morgan le Fay and the Enchantress might be seen as evil or good depending on what they use their powers for. Particularly he argues at one point about there can be two different levels of power that can be seen in social court structure. This is vital for the two enchantresses for each bring a knight ahead of his social court status to allow him to become something more. It has been argued that the medieval court, particularly from the thirteenth century on, was an especially good breeding-ground for magic. iii IF we follow Kieckhefer's lead in the idea of how magic can be obtain to gain more a of a power to separate one 
from social class structure it shows that these two women are truly fit for the role of being a created Goddess and helper to the knights they influence.

When compared to another source who bases the ideal view of magic from the traces of Celtic myth, Roger Loomis focuses on how magic can be interpreted in a more textual context based from prior authors who viewed it as sinful and heavenly being like. He examines the ideal views of how Morgan le Fay is someone who is described as Goddess from the moment she is introduced to the knight for her ability to transform his identity into someone more virtuous. Starting out as a woman who is mentioned in the stories written by Geoffrey of Monmouth, Morgan becomes a character that uses her powers for her own gain for the ability to change another. In the end it is up to the character she changes if he/she wishes to accept them or defy them. She is also mentioned in other tales that make her character development interesting for she tended to come and go within the texts over the centuries. Loomis talks about how Morgan's name can be traced back to numerous affiliations of Celtic Welsh powerful characters. Once Morgan appears and starts to interact with Arthur and his friends Loomis talks about how Morgan le Fay and the Lady of the Lake can be considered as one of the same. ${ }^{\text {iv }}$ Magical characters are needed to have a more in-depth analysis of what a person can be. Magic was seen as a positive notion in the texts, but when it came to the actual ideal world, it was frowned upon. What made it possible to allow this kind of writing to blossom in this time period? Obviously magic was considered as a hot topic since it was allowed to appear in the texts of King Arthur and his friends. In the end though it was truly seen as a way to separate a character from the social norm within the text. An outside force that was allowed to influence a certain character or characters to do some form of a good deed or bad deed.

Throughout texts the name of a woman in power with magic has changed greatly over time. Today the term used for someone who used magic is either an enchantress or a witch. Numerous sources that have been found today show Morgan and other fairies more than just a fairy, but an enchantress to give her more of a human like quality. For this paper the name of a fairy will be sued to talk about how magic was a key element giving them the fairy like qualities of having magic within themselves, a genetic code that was used to help others. Through exploring the idea of how fairy magic was needed in order to help these stories many knight such as Lancelot, Gawain, and other numerous characters like Author using Excalibur, were needed to heighten the story, but to also show a deeper side of needing outside perspective to help you rather than your own. Geoffrey of Monmouth allowed King Arthur and his friends grow next to each other in different directions with or without magic to give them a deeper meaning to the story. But it is also true that the name "fairy," a word not previously attached to the new mythical form that invades romance beginning in the twelfth century, was only just coming to be used. In spite of the impression of the qualifiers, we nevertheless need hardly hesitate about the fairy a nature of female characters. ${ }^{\mathrm{v}}$

Geoffrey of Monmouth was one of the first historians to write about these legendary characters and how magic allowed them to become something more than just a character in the texts. In "The Romance of Arthur: An Anthology of Medieval Texts Translations" editors Norris Lacy and James
Wilhelm both compile works done from authors who discuss Geoffrey of Monmouth's role in literature and various other authors who wrote about King Arthur and translate texts for better understandings. Geoffrey was seen as a historian who influenced and started the tales of King Arthur and his court through different idea structures that were influenced through Britain at this time. As audience we know that magic is relevant because in Geoffrey's writings about King Arthur he sues magic to change the characters. While ordered as history, Geoffrey's work dramatizes folklore and legend. Some leading elements of Arthurian fiction are introduced by him. He shows Arthur to be a figure of destiny, his reign foretold in the stars. ${ }^{\text {vi }}$ Geoffrey summarizes Arthur to be seen as a hero destined from day one, a prophetic hero that was determined by Merlin who told of great things happening within the kingdom.

Geoffrey does an excellent job of enticing his audience and using historical influences to make his work even more relevant with this time period of struggle between the King and his oppressors. When Geoffrey was hired to write he was wrote that he was puzzling over these gaps in the historical record. No such constructive accounts of what history was really like has come to light until Geoffrey was able write about a fictional character based off of Kings in Britain. ${ }^{\text {vii }}$ Through his historical writings audiences in the present day can piece together the references to social contexts such as how the King was behaving to how the ideal thoughts in the world, such as witchcraft, was popular and shaped its way into the texts. It is important to remember this when reading his works. The historical evidence of King Arthur being based off of different kings truly do reflect how unstable the land was in this time period. Constant changes in rulers along with invasions and unbalanced reflected deeply within Geoffrey's work. A person reading or listening to this tale would gain courage and hope from learning that King Arthur was balancing his kingdom and working towards a common goal that was needed for his own people. Geoffrey of Monmouth firsts introduces Morgan le Fay as a fairy who is related to her half sibling, King Arthur. With her introduction she is seen as someone who is neutral, but in the end she is penalized for her use of magic. By penalized it simply means that she has been seen as someone who is either evil or good by how you view her use of magic. Since she is the half sibling of Arthur it can be seen that she does have the same intentions of being a hero like her brother, but she disappears after awhile from the texts.

Morgan le Fay, a powerful sorceress, a fairy, an enchantress, all various names that have been given to her to make her seem powerful and different from those who are told in the legend of King Arthur. One of the other terms that has been used for her is witch and has resulted in a conversation about how Morgan can be seen as a woman of good intentions or evil. From the perspective of how she changes Gawain it can only be seen as appositive for she changed him for the better. At the beginning of the poem that was written by the Pearl poet we see the legendary court eating together at the round table. Each are in a jolly good mood filled with tons of food and gifts being passed around for everyone. The poet writes, 'then came to the court for caroling dancing, for the feat was in full force fifteen days, with all the meat and mirth that men could devise, such gaiety and glee glorious to hear, brave din by day, dancing by 
night' ${ }^{\text {'viii }}$ reflecting two weeks of joyous celebration, showing sins in greed, gluttony, and pride. This can be seen as a point in time where Arthur's court is in trouble and needs to be saved before it is too late. The solution is when Morgan, a fairy and Arthur's half sister, sends in a knight endowed with magic to trial one of the round table members in hopes of saving one if not, all. If we interpret this idea of how the round table was sinning then Gawain was indeed saved by the end of his tale from Morgan trialing him to his will desire and for him to self-reflect his goal in life. The knight in the beginning of the poem agrees to fight the Green Knight in order to show off his power, but to also prove that he is a real man who can protect the young King Arthur.

Morgan's power is seen as remarkable and unlike any other and results in her being known as a goddess or a witch. She is able to set outside of the social class restraints and become a heavenly being who trialed a man that surpassed her tests. Morgan, as a goddess, is ultimately responsible for the challenge and the quest. ${ }^{\mathrm{ix}}$ When we reach the conclusion of our tale it unfolds to show that a woman was actually in power allowing Gawain to be steered off the path of evil and back into the arms of justice. Gawain would not have been freed from his sin if it were not for Morgan. Even as feminist critics have, especially in the past two decades, convincingly shown that women are central to the poem's action, editors have obscured or even erased their role in the text ${ }^{\mathrm{x}}$ in attempts to keep Morgan's true power and role separate from the actual tale of Gawain and the Green Knight. Several critics see remnants of an Irish sovereignty goddess in medieval representations of the loathly lady, and form the beginning, she puts knights to a test. ${ }^{\mathrm{xi}}$ The evidence in uncanny to show that Morgan was the one behind the beheading game ${ }^{x i i}$ and resulted in Gawain taking on his trial for claiming himself as a justly man. Morgan's role in the stories tends to vary vastly upon how you view her and her use of magic. 'Authors tend to portray, and critics to analyze, the character of Morgan le Fay in dichotomous terms, as either a benevolent healer who tends to Arthur in his final battle or as an evil witch out to bring Arthur down, xiii resulting in a heated debate as to where Morgan's ligancy lies within the texts.

In the heated debate that is still seen greatly amongst authors the witch aspect of Morgan is seen through her role of wanting to harm Arthur and his round table. It is a double edge sword where instead of wanting to help Arthur and his friends authors interpret Morgan to wanting to harm them. In early Christian religious aspects the idea of an older woman using her own sources of medicine in attempts to heal another is seen as witchcraft ${ }^{\mathrm{xiv}}$ making a woman's view of alternate medicine a $\sin$ in the eyes of those who supported Christian beliefs. This is no surprise when it shows that witches are seen as natural healers and wish to help others. The fear is still there though when we see that the same medicine that could possibly heal you, can also, kill you. ${ }^{\mathrm{xv}}$ Morgan is interpreted as a witch or a fairy, each aid in the process of healing, but as a witch, she can be seen as wanting to kill those who come across her path. Gawain meets her in the castle and is told that she has been staying there as a guest, not harming anyone, but merely there for support and waiting for Gawain to appear. I truly believe that Morgan was there to help him and the others, not put there to just merely trick them, but to help them become a better person in life in order to try to save the predicted outcome of King Arthur's kingdom.

Like Morgan le Fay, a powerful fairy is known to shape the identity of another man within the texts around King Arthur's court; this man's name was Lanval. Lanval is seen immediately as man that does not fit into society. Nearly everyone has forgotten about him in the kingdom due to him being poor, nonsocial, and being introverted. Lanval's story is a true tragedy in the beginning because he use to serve for the King and in the end even the King forgot about the noble knight, Arthur forgot him, and none of his men favored him either. ${ }^{\mathrm{xvi}}$ Lanval is truly broken by being forgotten by one of the most powerful rulers that the country has ever seen. How could a king ever forget about someone who once served on his court? Lanval is broken hearted and not going anywhere in life besides a downward spiral and it all changes when he meets a fairy.

The fairy allows Lanval to break out of his social context of being forgotten and reappear as someone worthy of being noticed. The fairy gives Lanval money and in return this leads him to power, but like all magic, it comes with a heavy price. The fairy says to Lanval, 'Love, I admonish you now, I command and beg you, do not let any man know about this. I shall tell you why: you would lose me for good if this love were known; you would never see me again for possess my body. ${ }^{\text {xvii }}$ This shows the idea of a noble fantasy love where he can only know about the two of them and if anyone else were to find out then their love shall be broken. This is a lucky change for Lanval because his new companion has allowed him to rise way above the social rankings, making him even better than King Arthur to a certain degree. Arthur does have Guinevere, but she is not magically enhanced. The fairy has allowed Lanval to be with someone who is magically enhanced, outside of the social class structure, giving him the ranking of a higher nobleman. He might not even be considered as a nobleman, he might even be seen, as a God for how his wife will allow him to use magic at his will. If this fairy had not approached Lanval his life would have continued to go in a downward spiral lost in negativity and not being noticed. He does have a challenge when he denies Guinevere and she automatically assumes he is lying when he decides not to show an interest in her beauty. Lanval is honest and tells her that he is promised to another that has far more beauty than Guinevere herself. ${ }^{\text {xviii }}$ The Queen is so angered that she wishes to bring Lanval to the king and fight for his life. Even right here we see how Guinevere is attempting to do treason by trying to have an adulterous affair with a knight and gets even more furious when he continually denies her. ${ }^{\text {xix }}$ This shows one of many sides of Guinevere's vanity of needing to be desired by every man she sees. If it were not for Lanval and how he announces his love to another woman there would not have been a more powerful scene when the fairy comes in to claim her noble man.

The fairy that Marie de France describes and Morgan le Fay both express different ideas of how a fairy could act in this time period. The similarity of wanting to help another is very obvious when examining the two. Both wanted to help a knight that was one the path towards a destructiveness that would ruin them in the end. For Gawain it is seen with his greed and gluttony of feasting until the end of days with Arthur's court. His greed is also seen when he takes his year round journey to rediscover himself more in life. One of his 
more obvious forms of the sins is how is very prideful when approaching the knight, allowing him to be seen as someone who is arrogant and full of himself. Morgan allowed herself to intervene and help the man. Lanval's fairy intervenes when he has no one left. Giving him the boost of morale needed to live his life happily with instant money and love from being able to be with a heavenly being. One of the most interesting concepts of between the two fairies is how they both appear in the texts. Marie de France's fairy continues to be seen in a positive light due to her approaching a man and in return he can marry and spend eternity with her. In exchange he only needs to be silent when people ask about his relationship. It shows that there is some kind of spell there, not being able to confess about your love constantly, but he is allowed to be happy for the rest of his life. The fairy makes him happy and allows him to become a man. Morgna, on the other hand, just opens Gawain's eyes so that he notices what is going on around him. He notices Morgan in the texts and dismisses her instantly by her appearance, but if he would have paid attention more he might have seen the fairy within her. When Lanval meets his new companion, she is seen as a heavenly being that is even more gorgeous than Guinevere. Morgan, although she is powerful, is not given the serene grace of beauty.

Lanval's fairy truly graces others with her appearance by how beautiful she is. The fairy who contacted with Lanval is seen laying on her bed when he approaches her. 'Her body was well shaped and elegant; for the heat, she had thrown over herself, a precious cloak of white ermine, covered with purple alexandrine, but her whole side was uncovered, her face, neck, and her bosom; she was whiter than the hawthorne flower. ${ }^{\text {xx }}$ Compare this to Morgan who is seen as an older woman that is not attractive, but kind of looks more like a hermit, shows a big difference in desires of physical traits. In text written by the Pearl Poet the description of Morgan goes by, 'That was older than she-an ancient, it seemed, / And held in high honor by all men about' (948-49) and she is compared to an younger woman where the author does not make her seem harshly ugly or disfigured in any shape or form. 'As an old woman, Morgan takes the place of the crone, one of the manifestations of the Irish Goddess Mórrígan'xxi resulting in the idea of Morgan's relations to early Celtic magic might be seen as a sign of inspiration as to why magic became so popular in this time period. Morgan and the fairy in Marie de France's writing both encompass the idea of needing to improve the human race. If King Arthur's court was sinning and magic was used to try to stop it, but failed, then what could really be used to stop it? Nothing. The overlapping idea of foreshadow and what is to come of Arthur and his friends is seen greatly when Gawain comes back and they merely laugh him off about his trial with Morgan. Lanval is saved by his fairy, but, the never believed him when he said she was prettier than Guinevere. The fairy in the end had to save him and when she did they left. Leaving behind the society that treated them both poorly. One of the most crucial observances expressed in the text written by the Peal Poet is how Morgan is seen as a Goddess. Larissa Tracy states that 'Morgan, as a goddess, is ultimately responsible for the challenge and the quest ${ }^{\text {'xii }}$ resulting in a more respectful term for the trial that Morgan does to Gawain.

Magic played a constant role within the time period of King Arthur's great legend. Maybe these were hints of people needing their wishes to come true: to see a kingdom blossom with unity and love. Authors continued to write about King Arthur and his battle between pride and gluttony, to his death in Sir Malory's writings. If it were not for the role of magic and fairies certain characters would have been stuck in the loop of falling back into sin and repeating their own boring lives as nothing. Luckily fairies were created to help aid people in their time of need, especially for Sir Gawain and Lanval. If anything both of these works show that magic was needed in this time period to entice audiences everywhere to notice that life is not always what it seems. Both Morgan and the fairy from Marie de France's writing shows that magic was needed to bring a life lesson into these tales, the lesson being, do not sin and save yourself while you can. Lancelot uses his ring to help him see things more clearly. Another property of magic that is shown to aid a person in a positive direction and attempt to steer him clear from a downward spiral. His failed too, just like Gawain's, when no one listens to his plea for help. This was a common element in this time period, but had somewhat of a positive note was reflected within these two tales. A person can at times rely on someone else to approach him or her and guide him or her to the correct path. In this case two fairies were needed to bring good intentions back into two very well known knights.

\section{Works Cited}

Battles, Paul. "Amended Texts, Emended Ladies: Female Agency and the Textual Editing of "Sir Gawain and the Green Knight." Chaucer Review 44.3 (2010): 323-343. Academic Search Complete. Web. 8 Dec. 2014.

France, Marie de. The Lais of Marie de France. Trans. Robert Hanning and Joan Ferrante. Durham: The Labyrinth Press, 1978. Print.

Hebert, Jill M. Morgan le Fay, Shapeshifter. New York: Palgrave Macmillan, 2013. Print.

Jurasinski, Stefan. "Treason and the Charge of Sodomy in The Lai De Lanval." Romance Quarterly 54.4 (2007): 290302. Academic Search Complete. Web. 7 Dec. 2014.

Kieckhefer, Richard. Magic in the Middle Ages. New York: Cambridge University Press, 1989. Print

Lacy, Norris J., and James J. Wilhelm, eds. The Romance of Arthur: An Anthology of Medieval Texts in Translation. Third ed. New York: Routledge, 2013. Print.

Loomis, Roger S., ed. Arthurian Literature in the Middle Ages. London: Oxford University Press, 1959. Print.

Miyares, Rubén Valdés. "Sir Gawain and the Great Goddess." English Studies 83.3 (2002): 185. Academic Search Complete. Web. 7 Dec. 2014.

Poet, Pearl. The Gawain Poet: The Complete Works. Trans. Marie Borroff. New York: W.W. Norton Company, Inc., 2011. Print,

Wheeler, Bonnie, ed. Arthuriana. Dallas: Scriptorium Press, 2007. Print.

\section{Bibliography}

Ashton, Gail. Medieval English Romance in Context. New York: Continuum International Publishing Group, 2010. Print.

Battles, Paul. "Amended Texts, Emended Ladies: Female 
Agency and the Textual Editing of "Sir Gawain and the Green Knight." Chaucer Review 44.3 (2010): 323-343. Academic Search Complete. Web. 8 Dec. 2014.

Clarke, Basil. Life of Merlin. Cardiff: University of Wales Press, 1973. Print.

Fenster, Thelma S., ed. Arthurian Woman: A Casebook. New York: Garland Publishing, Inc., 1996. Print.

France, Marie de. The Lais of Marie de France. Trans. Robert Hanning and Joan Ferrante. Durham: The Labyrinth Press, 1978. Print,

Goodrich, Peter H., and Raymond H. Thompson, eds. Merlin: A Casebook. New York: Routledge, 2003. Print.

Hanning, Robert W. The Individual in Twelfth-Century Romance. London: Yale University Press, 1977. Print.

Hebert, Jill M. Morgan le Fay, Shapeshifter. New York: Palgrave Macmillan, 2013. Print.

Jurasinski, Stefan. "Treason And The Charge Of Sodomy In The Lai De Lanval." Romance Quarterly 54.4 (2007): 290-302. Academic Search Complete. Web. 7 Dec. 2014.

Karr, Phyllis A. The King Arthur Companion. University Of Chicago Press: Chaosium Inc., 1983. Print.

Kieckhefer, Richard. Magic in the Middle Ages. New York: Cambridge University Press, 1989. Print.

Lacy, Norris J., and James J. Wilhelm, eds. The Romance of Arthur: An Anthology of Medieval Texts in Translation. Third ed. New York: Routledge, 2013. Print.

Lacy, Norris J., Geoffrey Ashe, and Debra N. Mancoff. The
Arthurian Handbook. Second ed. New York: Garland Publishing, Inc., 1997. Print.

Larrington, Carolyne. King Arthur's Enchantresses: Morgan and Her Sisters in Arthurian Tradition. New York: I.B.Tauris \& Co. Ltd, 2006. Print.

Loomis, Roger S., ed. Arthurian Literature in the Middle Ages. London: Oxford University Press, 1959. Print.

Lupack, Alan. The Oxford Guide to Arthurian Literature and Legend. New York: Oxford University Press, 2005. Print.

Miyares, Rubén Valdés. "Sir Gawain and the Great Goddess." English Studies 83.3 (2002): 185. Academic Search Complete. Web. 7 Dec. 2014.

Neal, Derek G. The Masculine Self in Late Medieval England. Ontario: The University of Chicago Press, 2008. Print.

Paton, Lucy A. Studies in the Fairy Mythology of Arthurian Romance. Boston: Ginn \& Company, Publishers, 1903. Print.

Poet, Pearl. The Gawain Poet: The Complete Works. Trans. Marie Borroff. New York: W.W. Norton Company, Inc., 2011. Print,

Slocum, Sally K., ed. Popular Arthurian Traditions. Bowling Green: Bowling Green State University Popular Press, 1992. Print.

Walters, Lori J. Lancelot and Guinevere: A Casebook. New York: Routledge, 1996. Print.

Wynne-Davles, Marion. Women and Arthurian Literature. New York: St. Martin's Press, Inc., 1996. Print.

\section{Footnotes:}

${ }^{\mathrm{i}}$ Fenster, Thelma S., ed. Arthurian Woman: A Casebook. New York: Garland Publishing, Inc., 1996. Print, 148.

ii Kieckhefer, Richard. Magic in the Middle Ages. New York: Cambridge University Press, 1989. Print, 14

iii Kieckhefer 96

${ }^{\text {iv }}$ Loomis, Roger S., ed. Arthurian Literature in the Middle Ages. London: Oxford University Press, 1959. Print, 193.

${ }^{v}$ Thelma Fenster, 142.

${ }^{\mathrm{vi}}$ Lacy, Norris J., and James J. Wilhelm, eds. The Romance of Arthur: An Anthology of Medieval Texts in Translation. Third ed. New York: Routledge, 2013. Print, 59.

${ }^{\text {vii }}$ Norris J. Lacy and James J. Wilhelm, 59.

viii Poet, Pearl. The Gawain Poet: The Complete Works. Trans. Marie Borroff. New York: W.W. Norton Company, Inc., 2011. Print, 11.40-47, 202.

${ }^{\text {ix }}$ Wheeler, Bonnie, ed. Arthuriana. Dallas: Scriptorium Press, 2007. Print, 41.

${ }^{x}$ Battles, Paul. "Amended Texts, Emended Ladies: Female Agency and the Textual Editing of "Sir Gawain and the Green Knight." Chaucer Review 44.3 (2010): 323-343. Academic Search Complete. Web. 8 Dec. 2014, 322.

${ }^{x i}$ Hebert, Jill M. Morgan le Fay, Shapeshifter. New York: Palgrave Macmillan, 2013.Print, 55.

xii Paul Battles, 336.

xiii Jill Herbert, 1.

xiv Slocum, Sally K., ed. Popular Arthurian Traditions. Bowling Green: Bowling Green State University Popular Press, 1992. Print, 19.

${ }^{\mathrm{xv}}$ Sally Slocum, 19.

${ }^{\mathrm{xvi}}$ France, Marie de. The Lais of Marie de France. Trans. Robert Hanning and Joan Ferrante. Durham: The Labyrinth Press, 1978. Print, 105.

xvii Marie de France, 109.

xviii Marie de France, 112-113 
xix Jurasinski, Stefan. "Treason And The Charge Of Sodomy In The Lai De Lanval." Romance Quarterly 54.4 (2007): $290-302$. Academic Search Complete. Web. 7 Dec. 2014, 296.

${ }^{\mathrm{xx}}$ Marie de France, 107-108.

xxi Bonnie Wheeler, 41.

xxii Bonnie Wheeler, 41. 